\title{
Measuring Labor's Share of Income
}

by Paul Gomme and Peter Rupert

Recent Bureau of Labor Statistics (BLS) data show labor's share of income at a historic low. This Policy Discussion Paper explores the BLS calculations with an eye to understanding the factors leading to the recent fall in labor's share. While data limitations prohibit replication of the BLS series, alternative measures of labor's share of income, based on either the nonfinancial corporate business sector or the macroeconomy more generally, are near their historic averages, quite unlike the BLS series.

Policy Discussion Papers are published by the Research Department of the Federal Reserve

Bank of Cleveland. To receive copies or to be placed on the mailing list, e-mail your request

Paul Gomme and Peter Rupert are economic advisors at the Federal Reserve Bank of Cleveland. The authors thank Brian Rudick for excellent research assistance.
Materials may be reprinted if the source is credited. Please send copies of reprinted materials to the editor.

We invite questions, comments, and suggestions. E-mail us at editor@clev.frb.org.

Policy Discussion Papers are available electronically through the Cleveland Fed's site on the World Wide Web: www.clevelandfed.org/Research.

Views stated in Policy Discussion Papers are those of the authors and not necessarily those of the Federal Reserve Bank of Cleveland or of the Board of Governors of the Federal Reserve System. 


\section{Introduction}

A striking feature of the current expansion is the unusually low share of national income being earned by labor. According to recent Bureau of Labor Statistics data, labor's share of income is at a post-World War II low (see figure 1). There are at least a couple of reasons to be interested in the current low.

First, many have observed that the converse of labor's share is capital's share. The historically low labor share would then imply a historically high capital share. Said differently, the recent strength in productivity growth has largely accrued to capital, not to labor. As a result, growth in real hourly compensation (or real unit labor costs) has lagged behind productivity growth.

\section{FIGURE 1 LABOR SHARE AS REPORTED BY THE BUREAU OF LABOR STATISTICS}

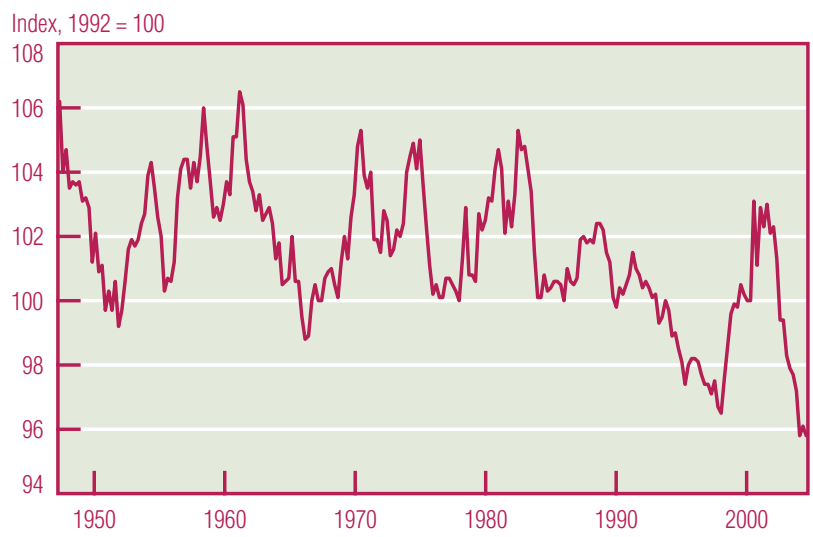

SOURCE: U.S. Department of Labor, Bureau of Labor Statistics.

Second, as labor markets improve, it is expected that labor costs will start to accelerate and labor's share will move back toward its historical average. As the story is most commonly told, the increase in costs could be inflationary as firms pass along these higher costs in the form of higher prices. This story relies, in large part, on firms maintaining a constant markup over costs. An alternative scenario begins with the fact that as labor's share of income rises, capital's share will fall, implying a fall in profit margins. But since these margins are at an all-time high, firms are willing to absorb some of the increased labor costs in terms of lower profits. One, perhaps optimistic, view is that the falling profit margins will offset the cost-push effects of higher unit labor costs, with little or no effect on inflation.

This Policy Discussion Paper has two purposes. The first is to explore the way in which the Bureau of Labor Statistics calculates its measure of labor's share of income. Knowing which sectors of the economy the Bureau of Labor Statistics has included (or excluded) from its measure enables us to evaluate the economywide implications of the fall in their labor's share series. Replicating the Bureau's calculations is a useful first step in evaluating the factors that led to the fall. This exploration is presented in Section 2.

The second purpose of this paper is to look at alternative measures of labor's share. Two alternative measures are considered, one for the nonfinancial corporate business sector, and the other for the macroeconomy more generally. Presumably the labor's share measure is used to describe how much of the returns to output are accruing to workers across the economy and how much to capital. One issue that arises in calculating such a measure is how to apportion proprietors' income because it includes both labor 
and capital income components. The nonfinancial corporate business sector is a convenient one to analyze because it has no proprietors' income. The second calculation considered builds on established thought in the academic literature. These alternative measures of labor's share are presented in Section 2.

Our analysis yields three basic conclusions. First, the "historic lows" in labor's share are observed only in the nonfarm business sector series produced by the Bureau of Labor Statistics. Other measures of labor's share-for example, for the nonfinancial corporate business sector or the macroeconomy more broadly-are currently near their averages over the last several decades.

Second, for labor's share as computed by the Bureau of Labor Statistics, a fall in labor's share does not necessarily imply a rise in capital's share; indirect taxes and subsidies constitute a wedge between these two series. Consequently, a fall in labor's share could be associated with a rise in capital's share, but it could also be due to a rise in the share of indirect taxes less subsidies. However, we find that the share of indirect taxes less subsidies does not vary much. Further, the terms "capital's share" and "profit share" are often used interchangeably, ignoring the fact that capital income derives from more sources than just (corporate) profits.

Finally, there is a cyclical pattern to labor's share: It rises during recessions and falls during expansions. The recent fall in labor's share (in the nonfinancial corporate sector, and in our broad macroeconomic measure)_back to its historic mean — is typical of the early part of a business cycle expansion. Whether these movements in labor's share have implications for monetary policy is an open question.

\section{Measuring Labor's Share}

One way of measuring output, or gross value added, for an economy is to add up all incomes — every dollar of income must ultimately be earned either by factors of production (capital and labor), or be confiscated by government. By definition, then,

$\begin{aligned} \text { GROSS VALUE ADDED }= & \text { COMPENSATION OF EMPLOYEES } \\ & + \text { CORPORATE PROFITS } \\ & + \text { RENTAL INCOME } \\ & + \text { NET INTEREST INCOME } \\ & + \text { PROPRIETORS' INCOME } \\ & + \text { INDIRECT TAXES LESS SUBSIDIES } \\ & + \text { DEPRECIATION } .\end{aligned}$

Of these income sources, compensation of employees is unambiguously labor income. Corporate profits, rental income, net interest income, and depreciation are unambiguously capital income. At first glance, then, computing labor's share of income appears straightforward: Divide compensation of employees by gross value added and we're done. But, as mentioned earlier, there is a problem concerning the apportionment of proprietors' income. 
Unfortunately, the deeper one digs into the national income and product account, the more one discovers that this simple calculation is woefully inadequate. Some important considerations that should be kept in mind when interpreting measures of the income shares include:

\section{- How should proprietors' income be divided between labor and capital?}

The consensus is that proprietors' income has components of both labor and capital income. But how should proprietors' income be divided between the two?

\section{- How should the government sector's lack of capital income be handled?}

In the government sector, there is no capital income: Value added by the government is simply wage and salary income plus consumption of fixed capital. Including the government sector biases the measured share of labor's income up, because government capital income is missing. Should we exclude the government sector or should we attempt to impute capital income to it?

\section{- How should the housing sector's lack of labor income be handled?}

The national income and product account imputes rental (that is, capital) income to owneroccupied housing, but does not impute any labor income. Including the housing sector biases the measured share of labor's income down because the labor income component of owneroccupied housing is omitted. Should the housing sector be excluded from our calculations, or should we try to impute labor income for this sector?

\section{- How should indirect taxes less subsidies be handled?}

What, if anything, should be done with indirect taxes less subsidies? We could simply do nothing, thereby recognizing that government absorbs part of value added. However, if government is excluded from the income measured, as discussed above, consistency calls for apportioning indirect taxes less subsides to both capital and labor income.

\section{- Should output (income) be measured on a gross or net basis?}

That is, should depreciation be included or excluded from our measure of output? Since gross value added measures total output produced in a sector, it is likely to be the preferred measure of output, particularly when addressing macroeconomic issues. However, if the shares of components of capital income are of interest, then net value added might be preferred since it avoids apportioning depreciation across these components. Using net value added because depreciation merely compensates owners of capital for the physical wear and tear of their capital is a weak justification: Labor is likewise subject to wear and tear, both physical and intellectual. Below, it will be shown that the decision of gross or net value added affects the level of labor's share of income. 
Measures of labor's share differ principally with regards to decisions made on these items. The remainder of this section analyzes three measures that involve different sets of these decisions and discusses the way in which the measures' interpretation is affected by such decisions.

\title{
The Bureau of Labor Statistics Methodology
}

The Bureau of Labor Statistics reports several labor's share series. For concreteness, consider labor's share for the nonfarm business sector; ${ }^{1}$ the methodology for other sectors is similar. Labor's share is defined as:

\author{
LABOR'S SHARE $=\underline{\text { LABOR COMPENSATION }}$ \\ VALUE ADDED
}

In turn,

$\begin{aligned} \text { LABOR COMPENSATION }= & \text { COMPENSATION OF EMPLOYEES } \\ & - \text { GOVERNMENT WAGES AND SALARIES } \\ - & \text { COMPENSATION OF EMPLOYEES OF NONPROFIT } \\ & \text { INSTITUTIONS } \\ - & \text { PRIVATE COMPENSATION (HOUSEHOLDS) } \\ - & \text { FARM COMPENSATION OF EMPLOYEES } \\ - & \text { HOUSING COMPENSATION OF EMPLOYEES } \\ + & \text { IMPUTED LABOR COMPENSATION OF } \\ & \text { SELF-EMPLOYED, }\end{aligned}$

where VALUE ADDED is defined to conform to the sectors included in computing LABOR COMPENSATION.

To start, notice that the Bureau of Labor Statistics has excluded the government and housing sectors. The farming sector has also been excluded, reflecting the particular subsector of the economy being measured. Less obvious is the Bureau of Labor Statistics' exclusion of nonprofit institutions and private compensation (households).

The Bureau of Labor Statistics handles the problematic issue of proprietors' income by dividing it as follows. First, the Bureau of Labor Statistics computes an implicit wage for this sector by dividing compensation by hours worked. Assuming the self-employed would pay themselves the same wage that they could otherwise earn in this sector, their implied labor income is this wage multiplied by hours of work by the self-employed.

\section{Replicating the Bureau of Labor Statistics' Labor's Share Series}

A first step toward understanding the behavior of labor's share of income and what may be causing its current level is to replicate what the Bureau of Labor Statistics has done. Replicating their calculations can allow us to see which components may be having the biggest effect on labor's share. Unfortunately, the attempt to replicate these calculations is hampered by data limitations. To start, while the Bureau of Labor Statistics' series of labor's share is reported quarterly, data for the housing and farm sectors are

1. BLS Series ID PRS85006173, available from http://www.bls.gov/ data; page down to Productivity \& Technology, look for Major Sector Productivity and Costs Index, select Create Customized Tables (One Screen). Assuming that you have Java loaded, select 8500 Nonfarm Business, Labor Share, and index, 1992=100. 
available only annually. A second important limitation concerns the hours data required for imputing labor compensation of the self-employed. Hours of the self-employed are available only from 1976, while hours of employees are available from 1964. Yet the Bureau of Labor Statistics' labor's share series starts in 1947.

\begin{tabular}{l|l} 
FIGURE 2 & REPLICATING THE BUREAU OF LABOR STATISTICS' CALCULATION OF LABOR'S SHARE
\end{tabular}

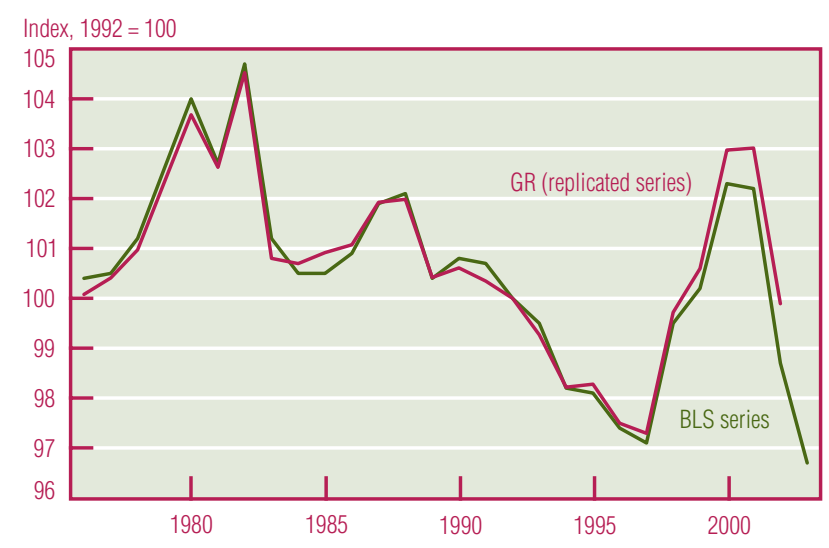

SOURCES: U.S. Department of Labor, Bureau of Labor Statistics; and authors' calculations based on NIPA data.

The upshot of these complications is that it is possible to replicate the Bureau of Labor Statistics' calculations only at an annual frequency, and only from 1976 to the present. Figure 2 presents the Bureau of Labor Statistics' labor's share series along with that computed by the authors (labeled GR). For the most part, the GR series follows that of the Bureau of Labor Statistics fairly closely. Since some of the data used in the GR series are available only until 2002, the GR series does not extend to 2003, when the Bureau of Labor Statistics' labor's share series falls most sharply. And, to be fair, it is not clear that the GR series might not have fallen precipitously as well, could it have been calculated.

\section{Another Approach to Ascertaining Income Shares: The Nonfinancial Corporate Business Sector}

In discussions of the movements in labor's share of income, it is not uncommon to see a fall in labor's share of income taken to necessarily imply a rise in profit's share. There are a couple of problems with this inference. First, profits are but one source of capital income. Second, indirect taxes less subsidies constitute a wedge between labor's share of income and capital's share of income. To get a handle on the relative sizes of these income components and of indirect taxes less subsidies, consider another measure of income shares, that of the nonfinancial corporate business sector. This choice has the virtue that neither proprietors' income nor rental income is included in the sector, thus avoiding the issues of properly apportioning proprietors' income to labor and capital or accounting for labor income in the housing sector. To avoid complications that might be presented by having to divide depreciation between corporate profits and net interest income, output is measured as net value added. 


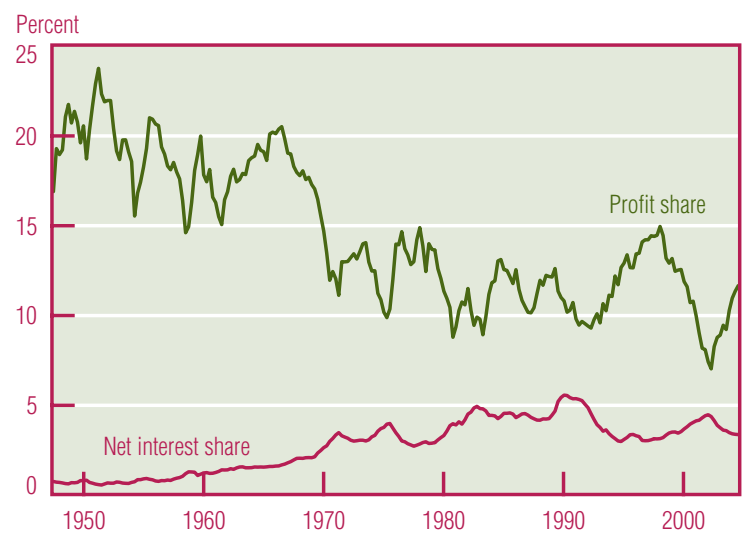

SOURCE: Authors' calculations based on NIPA data.

Figure 3 plots profits for the nonfinancial corporate business sector as a share of net value added as well as the share of net interest. One interesting fact is that profit's share fell in the early 1970s, while the share of net interest income rose until around 1980. Since 1970, profit's share for this sector has averaged 11.6 percent, while net interest income's share has averaged 3.8 percent. While it is true that profit's share rose sharply from 2001:IVQ to the present, keep in mind that at 7.0 percent in 2001:IVQ, profit's share was at its lowest level since World War II. In 2004:IQ, profit's share was 11.7 percent, little different from its average since 1970. Over the period 2001:IVQ to 2004:IQ, the share of net interest declined slightly.

The other problem just mentioned with taking labor's share as a reciprocal measure of profit is that it ignores other sources of income to capital. Indeed, the Modigliani-Miller theorem of corporate finance gives conditions under which a firm's financing decision—whether equity or debt—does not matter. A more accurate gauge of the income share earned by capital is obtained by adding all sources of capital income together. For the nonfinancial corporate business sector, that means adding profits and net interest income. This series is plotted in figure 4. Capital's share hit a low of 11.4 percent in 2001:IVQ, increasing to 15.0 percent by 2004:IQ. However, the current share is below its average of 15.5 percent when computed from 1970 to the present.

Also plotted in figure 4 is capital's share plus the share of net taxes-that is, one minus labor's share for this sector. Net taxes constitute a substantial wedge between capital's share and labor's share. Since 1970, the tax share has averaged 10.7 percent; at 11.0 percent in 2002:IQ, it was slightly above its average. While net taxes do create a wedge between capital's share and labor's share, figure 4 shows that movements in labor's share are primarily reflected in movements in capital's share.

Finally, labor's share is plotted in figure 5 . To be sure, labor's share has fallen sharply over the past few years, from 78 percent in 2002:IIIQ to 74 percent in 2004:IQ. However, this fall is relative to a post-World War II high. Today, labor's share is actually slightly above its average of 73.9 percent since 1970. This labor's share series gives a much different picture of labor's share of income than that provided by the Bureau of Labor Statistics' labor's share series. 


\section{FIGURE 4 SHARE OF VALUE ADDED, NONFINANCIAL CORPORATE BUSINESS SECTOR}

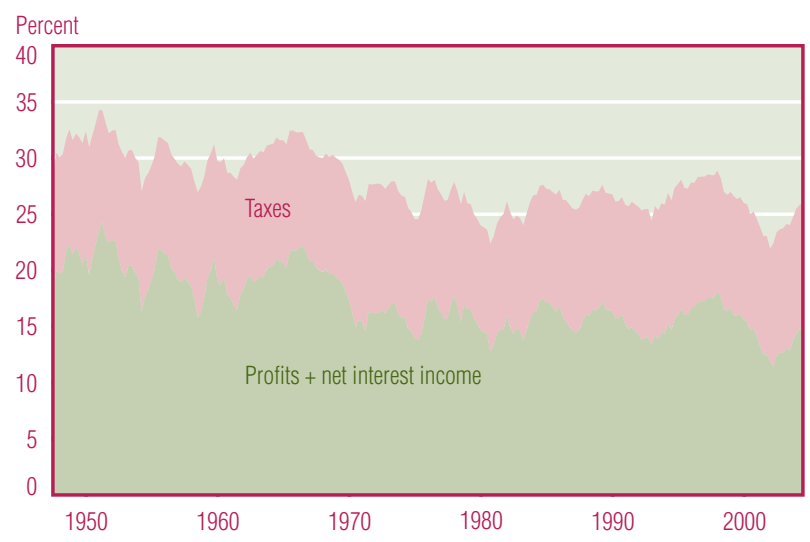

SOURCE: Authors' calculations based on NIPA data.

\section{Gauging Income Shares from a Macroeconomic Perspective}

There is a fairly long academic history regarding the measurement of labor's share of income; some key references include Kaldor (1956), Solow (1958), Prescott (1986), and Poterba (1998). One of Kaldor's "long-run growth facts" is the relative constancy of labor's share. Indeed, this fact is so ingrained in many macroeconomists that it is almost sacrilege to use an aggregate production function other than Cobb-Douglas, since this production function implies a constant share of income going to labor. That is to say, if labor's share has shown a distinctive trend, it would go against what most macroeconomists store in their bag of facts.

What follows is a fairly typical description of how labor's share is computed in the macroeconomics literature; for more details see Gomme and Rupert (2003).

To sidestep complications discussed at the start of Section 2, the government and housing sectors are typically excluded; doing so makes for fairly clean computations. This approach has not been uniformly adopted in the macroeconomics literature. In particular, Cooley and Prescott (1995) measure economic activity very broadly. Consequently, they impute capital income flows not only to government capital, but also to consumer durables. With respect to the issue of categorizing proprietors' income and indirect taxes less subsidies, the consensus in the literature is that this "ambiguous" income should be allocated to labor and capital in the same proportions they represent in the remainder of the economy. In particular, let $Y^{U L}$ denote unambiguous labor income (compensation of employees), $Y^{U K}$ be unambiguous capital income (corporate profits, rental income, net interest income, and depreciation), and $Y^{A}$ be ambiguous income (proprietors' income plus indirect taxes less subsidies). Then, total labor income, $Y^{L}$, would be

$$
Y^{L}=Y^{U L}+a Y^{A}
$$

where $a$ is labor's share of income, as yet undetermined. Since $a$ is labor's share of gross value added, $Y$, it follows that

$$
Y^{L}=a Y=a\left(Y^{U L}+Y^{U K}+Y^{A}\right) .
$$




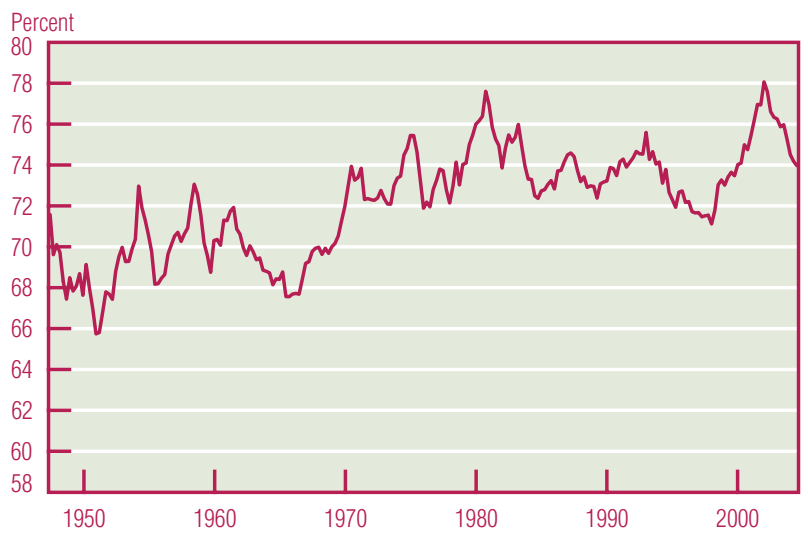

SOURCES: Authors' calculations based on NIPA data.

These two equations can be solved for labor's share:

$$
a=\frac{Y^{U L}}{Y^{U L}+Y^{U K}} \text {. }
$$

Figure 6 plots $a$ over the period 1929 to 2002, the last year for which all the required data are available. While there have been sizeable swings in labor's share, this series exhibits remarkable stability over longer periods of time. Average labor's share since 1970 is 71.7 percent_coincidentally its value in 2002.

Also plotted in figure 6 are NBER recessions. In general, labor's share rises during recessions and falls early in an expansion. These observations suggest that the rise in labor's share leading up to 2001 and its subsequent fall in 2002 are part of the usual ebb and flow associated with business cycle fluctuations.

\section{Do Fluctuations in Labor's Share Have Inflationary Consequences?}

Not necessarily. Gomme and Greenwood (1995) and Boldrin and Horvath (1995) have put forth explanations of the countercyclical pattern on labor's share of income that are part of an optimal risk-sharing arrangement between firms and workers.

To understand the risk sharing in these papers, consider a more familiar example, home insurance. ${ }^{2}$ Most years, the homeowner makes a modest payment to the insurance company, and nothing happens to the house. Every so often, though, a catastrophic event occurs (for example, the house is destroyed in a fire), and the insurance company makes a large payment to the homeowner. An economic interpretation of the homeowner's behavior is that he is insuring his wealth across states of nature. In this case, the states of nature are "no loss" and "house destroyed." With insurance, the homeowner's wealth is the same across these states of nature.

A key element of Gomme and Greenwood (1995) and Boldrin and Horvath (1995) is the reasonable proposition that workers prefer relatively smooth, predictable patterns to their income. For example, most workers would prefer a constant $\$ 50,000$ per year rather than income of $\$ 20,000$ in one year followed by $\$ 80,000$ in the next. Workers would, then, presumably be willing to purchase insurance against business-cycle-induced variation in their incomes. Just as the homeowner makes a payment to the insurance company when times are good (the house does not burn down), workers would pay the 
insurance company during expansions. And just as the insurance company pays the homeowner when times are bad (the house burns down), it would pay the worker during recessions.

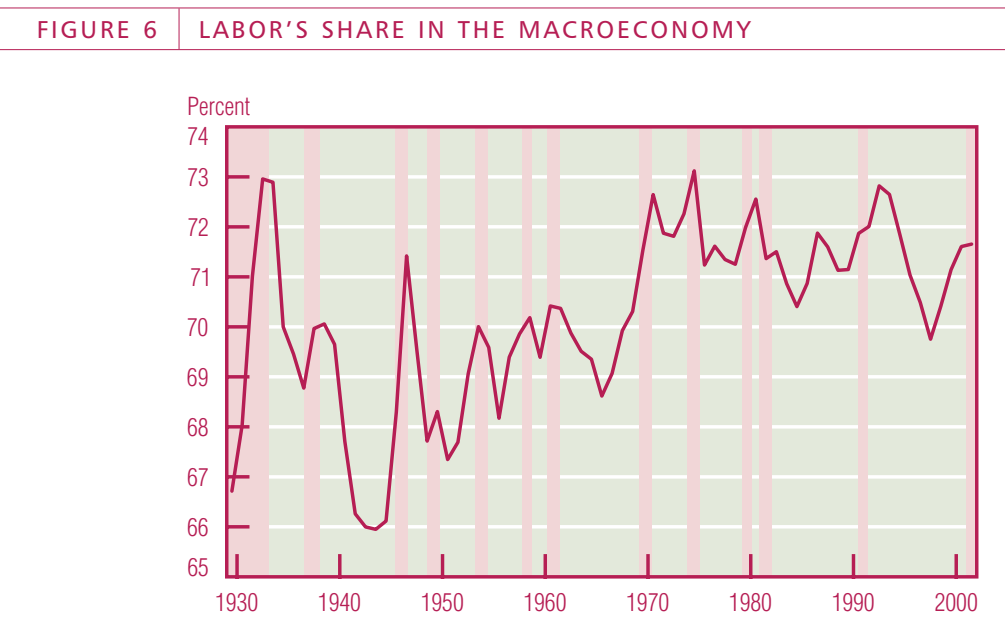

SOURCES: National Bureau of Economic Research; and authors' calculations based on NIPA data.

In practice, insurance companies do not offer such "business cycle insurance.” Why not? In large part because workers have at least some control over their incomes. Because workers can influence their own income, the insurance company would find it difficult to distinguish between a worker whose income is low because of external factors, such as business cycle fluctuations, and a worker whose income is low because he did not work very hard. In this case, "not working hard" is not unlike the homeowner burning down his own home in order to collect the insurance.

While an insurance company may find it difficult to ascertain the reasons a worker's income is low, the firm employing that worker should have a much better idea concerning the cause. Furthermore, firms presumably are less interested in smoothing their incomes than workers are in smoothing theirs. There is a potential gain if firms could, in effect, offer income insurance to workers as part of the wage contract, thus binding the provision of insurance with an effective means of monitoring the worker's actions. Provision of this income insurance need not be explicit. Rather, there is an implicit understanding that firms will not immediately cut wages or their workforce when the firm experiences a drop in demand. As a result, the labor income received by a worker includes not only compensation for output produced, but also insurance flows against aggregate cyclical risk.

Suppose that compensation for output produced is a constant fraction of output, as is the case if the aggregate production function is Cobb-Douglas; this portion of worker income does not move with the cycle. The insurance flows will be countercyclical: Workers receive an insurance payout when times are bad, and pay into the insurance when times are good. Thus, total labor compensation, including the insurance flows, will necessarily move countercyclically as well. It is to be expected that labor's share of income will be high during recessions and low during expansions. Gomme and Greenwood (1995) and Boldrin and Horvath (1995) show that accounting for these implicit insurance flows leads to empirically plausible fluctuations in labor's share of income. 


\section{Concluding Remarks}

First, the "historic lows" in labor's share are only observed in some series produced by the Bureau of Labor Statistics. Other measures of labor's share- for example, for the nonfinancial corporate business sector, or the macroeconomy more broadly—are currently near their historic average.

Second, for labor's share as computed by the Bureau of Labor Statistics, a fall in labor's share does not necessarily imply a rise in capital's share; indirect taxes less subsidies constitute a wedge between these two series. Consequently, a fall in labor's share could be associated with a rise in capital's share, but it could also be due to a rise in the share of indirect taxes less subsidies. However, as shown for the nonfinancial corporate business sector, the share of indirect taxes less subsidies does not vary much. Further, the terms "capital's share" and "profit share" are often used interchangeably, ignoring the fact that capital income derives from more sources than just (corporate) profits.

Finally, there is a cyclical pattern to labor's share: It rises during recessions and falls during expansions. The recent fall in labor's share- back to its historic mean —is typical of the early part of a business cycle expansion. Whether these movements in labor's share have implications for monetary policy is an open question. Gomme and Greenwood (1995) and Boldrin and Horvath (1995) have shown that the observed countercyclical behavior of labor's share of income may be part of an optimal risk-sharing arrangement between firms and workers.

\section{References}

Boldrin, Michael, and Horvath, Michael. "Labor Contracts and Business Cycles." Journal of Political Economy, 103 (October 1995): 972-1004.

Cooley, Thomas, and Prescott, Edward C. "Economic Growth and Business Cycles." In Thomas Cooley, editor, Frontiers of Business Cycle Research, Princeton, N.J.: Princeton University Press (1995): 1-38.

Gomme, Paul, and Greenwood, Jeremy. "On the Cyclical Allocation of Risk." Journal of Economic Dynamics and Control, 19 (January 1995): 91-124.

Gomme, Paul, and Rupert, Peter. "A Guide to Calibration." (2003). Unpublished manuscript, the University of Iowa and the University of Western Ontario.

Kaldor, Nicholas. "Alternative Theories of Distribution." Review of Economic Studies, 23 (February 1956): 83-100.

Poterba, James M. "Rate of Return to Corporate Capital and Factor Shares: New Estimates Using Revised National Income Accounts and Capital Stock Data." Carnegie-Rochester Conference Series on Public Policy, 48 (June 1998): 211-46.

Prescott, Edward C. "Theory Ahead of Business Cycle Measurement." Federal Reserve Bank of Minneapolis Quarterly Review, 10 (Fall 1986): 9-22.

Solow, Robert M. "A Skeptical Note on the Constancy of Relative Shares." American Economic Review, 48 (September 1958): 618-31. 